\title{
Discussion on the Accounting Management Mode after the Enterprization
}

\author{
Can LIAN \\ Finance \&Planning Department \\ Shenzhen Polytechnic \\ Shenzhen, China \\ E-mail: uoa18@163.com
}

\author{
Yao-Ju WANG \\ Teaching Affairs Department \\ Shenzhen Polytechnic \\ Shenzhen, China \\ E-mail: 1114811@qq.com
}

\begin{abstract}
The institution is the main carrier of the social management and public service function, it's an important part of the government's economic and social management, it has a very important role in the national economy and the people's livelihood. In this paper, we discussed how to realize the transformation of the institution accounting system to the enterprise accounting system.
\end{abstract}

\section{Keywords: institution, enterprise, Accounting}

\section{THE FEASIBILITY OF THE TRANSFORMATION OF INSTITUTION ACCOUNTING SYSTEM TO ENTERPRISE} ACCOUNTING SYSTEM.

Enterprise accounting and nonprofit accounting units consist of two major systems of modern accounting, accounting institution belongs to a kind of budget accounting, along with the development of market economy and the establishment of economic society, economy and the deepening of financial reform and improve the budget accounting functions accordingly and broaden the development, change the budget unit the accounting subject status and strengthen, as a special system of independent institutions, non-profit organization, and enterprise accounting difference gradually reduced, the two is the development direction of the gradual convergence.

Institution accounting system and enterprise accounting system has many similarities, the first is the premise of accounting system of two kinds of the same, including accounting, business activities, the accounting period and currency; in terms of accounting principles, the two also followed the same principles, such as the principle of authenticity and relevance in principle, the principle of comparability, the principle of consistency; both in accounting elements. Although there are some differences, but both in the content and method of roughly the same, such as accounting elements include assets, liabilities, owner's equity, revenue, cost and profit of six. Accounting elements of institutions include assets, liabilities, net assets, income and expenditure five. The definition, content and characteristics of the same elements. On the other hand, it is consistent with the application of accounting analysis in the setting of accounting subjects, the contents of accounting items and the application of financial analysis methods

. As Chinese economy and the deepening of financial reform and improve the institutions from the pure expenditure allocated by the state to change the balance of payments, or quota approved targeted subsidies, cost overruns do not fill, balance of retained mode of management, project budget and content of diversified development, gradually emphasize cost accounting, pay attention to efficiency in the use of cash and capital. The consistency stipulated in the accounting system and accounting system of enterprises and institutions and the content has a certain extent, in the information quality requirements, report elements recognition and measurement principles, methods and contents of the report in terms of assets, liabilities, income, expenditure and other aspects of the provisions of the same accounting principles and methods consistent statements which is basically the same, owner's equity and profit, net assets and the balance is actually the assets and liabilities and income and expenditure measurement results, is essentially the same. Therefore, enterprises and institutions not only in the principles of accounting and reporting on the consistency of the theoretical guidance, but also in the recognition, measurement methods are consistent principle.

\section{THE PROBLEMS OF ACCOUNTING MANAGEMENT SYSTEM IN INSTITUTIONS}

\section{A. Asset Accounting Methods}

In the present accounting system in institutions assets accounting, non-depreciable assets, only accounting book value, by extracting the maintenance fund to guarantee institutions to update and maintenance of fixed assets. The present accounting system in institutions, valuation of fixed assets fixed assets fixed assets increase, from fixed assets, inventory shortage, overage such accounting issues prescribed accounting methods in detail, but the provisions of the accounting value of fixed assets loss during use is not clear. Because do not reflect the net value of fixed assets, book value and net value of fixed assets has a lot of problems, with the use of time, place value from the original value of fixed assets, does not reflect the wear of fixed assets, inflated total assets, net assets of the actual situation of index balance sheet assets cannot reflect the assets. Because the cost does not include the daily cost, the cost accounting is not complete. On the one hand, the business unit in the purchase of fixed assets, debit "business expenses - equipment purchase fees" or "special fund, maintenance fund" or "fund expenditure" and other subjects, so the inflated cost accounting business; on the other 
hand, non-depreciable assets, artificially reducing the cost to obtain the corresponding income the inflated earnings ratio, and cannot really reflect the principles of accounting.

\section{B. Accounting Basis}

The "accounting standards for institutions trial" sixteenth provides that the budget unit accounting generally use the cash basis, but the business accounting can be used accrual basis". On the basis, institutions often have some fiscal year budget project case, resulting in some institutions on the cash basis accounting, not completely reflect the economic and business units. Such as institutions in a number of non-recurring expenses, in the event of the cost of the period, spending increases, resulting in reduced balance. So that the current balance of payments, the balance is not a real balance. Especially after the implementation of government procurement and centralized treasury payment system, procurement and payment of phase separation, and makes the implementation of the project payment pay certain time intervals, such as the accounting system of the existing institutions in the procurement and payment processing, interval year, there will be serious account doesn't accord with the reality, not true reflect the economic business unit.

\section{Cost Accounting}

At present, in the system of institutions, there are business operations in operating institutions, and the two are based on different accounting basis. Under normal circumstances, the institutions of the business operation of accrual basis, cost accounting for non-operating business using cash to achieve the system, no cost accounting. It is difficult to evaluate and assess the performance of the funds for non-operating business because of the lack of cost. In addition, due to the fact that the two kinds of business are not easy to distinguish in the actual work, the cost is difficult to be allocated reasonably, and the cost cannot be accurately accounted for. This is not only detrimental to the internal management of institutions, is not conducive to the effective use of state budget funds, but also easily lead to the loss of state assets. Therefore, the operation of institutions to carry out a comprehensive cost accounting is more conducive to saving money and improve operational efficiency.

\section{MEASURES FOR IMPROVING THE FINANCIAL SYSTEM OF ENTERPRISE MANAGEMENT INSTITUTIONS}

\section{A. Setting Reasonable and Unified Accounting Subjects}

In the transition period of reform of enterprises and institutions, from the accounting standard, management institution accounting content will be on both sides to differentiation management institution, business unit of the accounting standard will be closer to the budget accounting, and has the construction needs of the enterprise nature, enterprise management or the Department will close to the enterprise Accounting. After the commercialization of institutions, Business cost management can be allocated by the state to adopt financial institutions accounting standards, institutions in the accounting setting, should be in accordance with the requirements of the new accounting system, combined with the characteristics of management of enterprise, the new accounting system in general subjects. For those who cannot reflect the financial activities of institutions, but in the accounting work of institutions and very important subjects, you can set up a separate. According to the nature of the funds allocated, by setting up two levels of accounts. Such as "equity" subjects, cannot accurately reflect the funding institutions subject, can according to the characteristics of the source of funds, set up a subject "paid in capital", to reflect the actual funds received by an institution. In addition, you can also set up according to the needs of the cause of the surplus account, belonging to the owner's equity category used to reflect the institutions through a variety of channels to be used for the development of the unit's own funds. And in the "financial costs" and "management fees", but also can add a "business expenses" subjects, accounting for certain institutions in the course of the development of the cause of the various costs. .

\section{B. Establishing A Scientific Method of Fixed Assets Accounting $S$}

After the commercialization of institutions, Should build fixed assets accounting according to the enterprise accounting system, set up in fixed assets construction, use, disposal, select the appropriate method for the depreciation of fixed assets, and the addition of "depreciation" subjects, makes the accounting can reflect the value of the loss of fixed assets. According to different circumstances, in the transformation of institutions in the cost accounting for depreciation costs, the cost of accounting institutions can not only carry out depreciation expenses. The specific approach is: in each financial year end reporting statement, to fill in a detailed reflection of fixed assets or statements, and according to the actual amount of depreciation of fixed assets at the end of the year, the first annual reporting budget report, Shen column depreciation fund plan, budget reporting made depreciation fund appropriation, and included in the special subjects, for later use. In the need to update the fixed assets, the same need to report to the competent authorities for approval, the need to update the examination and verification before the depreciation fund to pay for the use of...

\section{Constructing A Reasonable Cost Accounting Model}

In view of how to construct a reasonable model of cost accounting, the accounting institutions generally use the cash basis, but some out of business management requirements and cost accounting, to the accrual basis, can use the accrual accounting basis. Appropriate accrual basis accounting is conducive to strengthening the cost control, reflecting the business activities of the business unit to achieve the integration of planning, budgeting, control and reporting. Has the system as the basis of accounting institutions with responsibilities, taking into account national appropriation expenditure management institutions still use accounting financial criteria, establish an internal control system is feasible, the strict distinction between operating income and financial income. In the early stage of the enterprise management, the accounting standards are mainly used in the enterprise accounting standards, and the accounting standards 
of financial institutions. That is, in the general ledger and statements in the use of corporate financial standards reflect the cause of the financial institutions to use financial institutions in accordance with the schedule and the way to explain the instructions.

In addition, after the management of enterprise financial personnel, many financial awareness unable to adapt to the new situation, widespread financial awareness is not in place, the focus on financial management, financial management and incremental compliance management, and asset management, stock management and asset performance management, accounting confusion, financial information distortion outstanding issues. Therefore, after the implementation of enterprise management institutions should intensify the financial staff training, to update the financial personnel business knowledge, improve accounting standards, and gradually make the financial management of the institution to standardize the management of financial institutions to enterprises as soon as possible.

\section{CONCLUSION}

In short, in the face of the existence of accounting management in enterprise management problems, financial institutions should change the idea, change the accounting method; must be based on the objectives of management accounting as the control basis, overcome the short-term behavior; Establish cost management and control methods to adapt to management accounting, strengthening cost management; strengthen the management of accounting personnel professional quality. In practice the institution of management accounting problems still exist, which requires institutions in the daily management should be based on its own characteristics, continue to explore the management accounting system to establish institutions.

\section{REFERENCES}

[1] JieLin, several problems of accounting calculation in institutional transformation of institutions [J], accounting communication, June 2004

[2] YongZhang, YichenZhao, on the possibility of the combination of enterprise accounting system and enterprise accounting system in our country [J], Journal of Liaoning Administration College, January 2005

[3] FanZhang, YaohuaZhang. Problems and Countermeasures in the restructuring of operating institutions [J]. Rural economy and technology, March 2005. 